\title{
$\alpha-M M C$ and MAP30, two ribosome-inactivating proteins extracted from Momordica charantia, induce cell cycle arrest and apoptosis in A549 human lung carcinoma cells
}

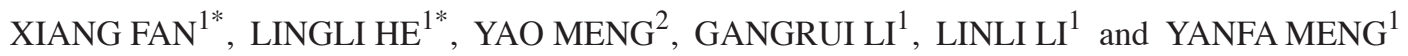 \\ ${ }^{1}$ Key Laboratory of China Ministry Education for Bio-Resources and Eco-Environment/ \\ Animal Disease Prevention and Food Safety Key Laboratory of Sichuan Province, College of Life Sciences, Sichuan \\ University, Chengdu, Sichuan 610065; ${ }^{2}$ School of Medical Laboratory Science, \\ Chengdu Medical College, Chengdu, Sichuan 610500, P.R. China
}

Received February 17, 2014; Accepted November 20, 2014

DOI: $10.3892 / \mathrm{mmr} .2015 .3176$

\begin{abstract}
Momorcharin ( $\alpha$-MMC) and momordica anti-human immunodeficiency virus protein (MAP30), produced by Momordica charantia, are ribosome-inactivating proteins, which have been reported to exert inhibitory effects on cultured tumor cells. In order to further elucidate the functions of these agents, the present study aimed to investigate the effects of $\alpha$-MMC and MAP30 on cell viability, the induction of apoptosis, cell cycle arrest, DNA integrity and superoxide dismutase (SOD) activity. $\alpha$-MMC and MAP30 were purified from bitter melon seeds using ammonium sulfate precipitation in combination with sulfopropyl (SP)-sepharose fast flow, sephacryl S-100 and macro-Cap-SP chromatography. MTT, flow cytometric and DNA fragmentation analyses were then used to determine the effects of $\alpha-M M C$ and MAP30 on human lung adenocarcinoma epithelial A549 cells. The results revealed that A549 cells were sensitive to $\alpha$-MMC and MAP30 cytotoxicity assays in vitro. Cell proliferation was significantly suppressed following $\alpha-\mathrm{MMC}$ and MAP30 treatment in a dose- and time-dependent manner; in addition, the results indicated that MAP30 had a more potent anti-tumor activity compared with that of $\alpha-\mathrm{MMC}$. Cell cycle arrest in S phase and
\end{abstract}

Correspondence to: Professor Yanfa Meng, Key Laboratory of China Ministry Education for Bio-Resources and Eco-Environment/Animal Disease Prevention and Food Safety Key Laboratory of Sichuan Province, College of Life Sciences, Sichuan University, Wu Hou Street, Chengdu, Sichuan 610065, P.R. China E-mail: flxyy_00737@163.com

${ }^{*}$ Contributed equally

Abbreviations: SOD, superoxide dismutase; RIP, ribosome inactivating protein; NBT, nitrotetrazolium blue chloride

Key words: ribosome-inactivating protein, anti-tumor activity, cell cycle, apoptosis, DNA integrity, superoxide dismutase activity, pyrogallol autoxidation method, nitrotetrazolium blue chloride activity staining a significantly increased apoptotic rate were observed following treatment with $\alpha$-MMC and MAP30. Furthermore, DNA integrity analysis revealed that the DNA of A549 cells was degraded following treatment with $\alpha$-MMC and MAP30 for $48 \mathrm{~h}$. The pyrogallol autoxidation method and nitrotetrazolium blue chloride staining were used to determine SOD activity, the results of which indicated that $\alpha$-MMC and MAP30 did not possess SOD activity. In conclusion, the results of the present study indicated that $\alpha$-MMC and MAP30 may have potential as novel therapeutic agents for the prophylaxis and treatment of cancer.

\section{Introduction}

Momordica charantia, also known as bitter gourd, is a widely cultivated crop in Asia and Africa, which has been used in the traditional medicinal systems of numerous cultures, including those of South Asia, China and South America, for health maintenance and the treatment of chronic diseases (1-4). $\alpha$-Momorcharin $(\alpha-\mathrm{MMC})$ and momordica anti-human immunodeficiency virus protein (MAP30), extracted from Momordica charantia seeds, are members of the type-I ribosome-inactivating protein (RIP) family, which inactivate ribosomes via depurination of the adenine base at position 2543 of $28 \mathrm{~S}$ ribosomal (r)RNA, inhibiting ribosomal protein synthesis in cells (5-7). In addition to its $N$-glycosidase activity, MAP30 has been reported to inhibit human immunodeficiency virus (HIV) integrase, topologically inactivate viral DNA irreversibly as well as selectively attack tumor-transformed and HIV-infected cells (8-12). In addition, $\alpha$-MMC has been demonstrated to have significant anti-tumor bioactivites $(13,14)$. Certain RIPs have been reported to exhibit superoxide dismutase (SOD) activities; SOD is an indispensable antioxidant, which removes $\mathrm{O}_{2}{ }^{-}$in order to prevent damage to the body $(15,16)$. However, there are a limited number of studies which have reported the SOD activity of RIPs extracted from Momordica charantia (17). Deciphering the molecular mechanism by which $\alpha$-MMC and MAP30 impart their protective anti-tumor effects is important as it may elucidate novel therapeutic methods for interfering with cancer development. The present study aimed to investigate the effects of $\alpha$-MMC and MAP30 on cell viability, the induction of apoptosis, cell cycle 
arrest and DNA degradation in human A549 lung adenocarcinoma epithelial cells. In addition, the SOD activities of $\alpha$-MMC and MAP30 were determined using pyrogallol autoxidation methods and nitrotetrazolium blue chloride (NBT) staining.

\section{Materials and methods}

Materials. Acr, Bis, trypsin, RNase A, propidium iodide, MTT and NBT were obtained from Sigma (St. Louis, MO, USA) and bitter melon seeds were obtained from the Institute of Agricultural Science and Technique of Sichuan Province (Chengdu, China). Protein makers were purchased from New England Biolabs (Ipswich, MA, USA). $\mathrm{NaH}_{2} \mathrm{PO}_{4}$, $\mathrm{Na}_{2} \mathrm{HPO} 4, \mathrm{NaCl}$, acetic acid, ammonium sulfate, SDS, dimethylsulfoxide, ethanol, phenol, Tris and EDTA were purchased from Sinopharm Chemical Reagent Company (Shanghai, China). Coomassie brilliant blue R-250 was purchased from XiYa Company (Chengdu, China). Proteinase $\mathrm{K}$ was obtained from Merck Millipore (Darmstadt, Germany). Agarose was purchased from Amresco LLC (Solon, Ohio, USA). Human lung adenocarcinoma epithelial A549 cells and human liver carcinoma HepG-2 cells were provided by the American Type Culture Collection (Manassas, VA, USA). The 96-well plates were purchased from Corning Inc. (Corning, NY, USA) and cisplatin was the product of Qilu Pharma (Jining, China). Dulbecco's modified Eagle's medium (DMEM) was obtained from Gibco-BRL (Carlsbad, CA, USA). Bovine serum albumin was purchased from Hyclone Laboratories, Inc. (Logan, UT, USA). Sulfopropyl (SP)-sepharose fast flow (FF), sephacryl S-100 and macro-Cap-SP were obtained from GE Healthcare (Little Chalfont, UK). The inverted microscope Olympus CKX41SF (Olympus, Tokyo, Japan) and the Unico UV-2012 PC spectrophotometer (Shanghai Unico Instrument Corp., Shanghai, China) were used. BT100M peristaltic pump was purchased from Chuangrui (Baoding, China). POWER-PAC300 electrophores and the Bio-Rad 680 microplate spectrophotometer were obtained from Bio-Rad Laboratories Inc. (Hercules, CA, USA). A JY-02S UV-transilluminator was obtained from YunYi (Beijing, China) and the Cytomics FC 500 flow cytometer was purchased from Beckman Coulter, Inc. (Fullerton, CA, USA).

Purification of $\alpha-M M C$ and MAP30. Unless specifically stated, all steps in the process of purification were performed at $4-6^{\circ} \mathrm{C}$. According to the purification method of $\alpha$-MMC and MAP30, as previously described (18), the powder from bitter melon seeds was extracted with $20 \mathrm{mM} \mathrm{pH} 6.5$ phosphate buffer (PB) with $0.15 \mathrm{M} \mathrm{NaCl}$ for $12 \mathrm{~h}$ and then centrifuged at $1,000 \mathrm{x} \mathrm{g}$ for $30 \mathrm{~min}$. Following adjustment of the $\mathrm{pH}$ of the supernatant to 3.6 using acetic acid, it was centrifuged at $1,000 \mathrm{x} \mathrm{g}$ for $15 \mathrm{~min}$. The supernatant was then neutralized to $\mathrm{pH} 7$ with $1 \mathrm{M} \mathrm{PB}$ and fractionated using precipitation with ammonium sulfate (30-60\%). The precipitate was dissolved and dialyzed against $20 \mathrm{mM} \mathrm{PB} \mathrm{(pH} \mathrm{7.0)} \mathrm{and} \mathrm{the} \mathrm{dialyzed} \mathrm{sample} \mathrm{was} \mathrm{passed}$ through the SP-sepharose FF column, equilibrated with the dialysis buffer and eluted with $20 \mathrm{mM} \mathrm{PB}(\mathrm{pH}$ 6.5) containing $0.15 \mathrm{M} \mathrm{NaCl}$. The eluted protein was then loaded onto the sephacryl S-100 and macro-Cap-SP columns in sequence and eluted using a linear gradient of $0.05-0.15 \mathrm{M} \mathrm{NaCl}$ in $20 \mathrm{mM} \mathrm{PB}$ (pH 6.0), with a flow rate of $1 \mathrm{ml} / \mathrm{min}$ achieved using a BT100M peristaltic pump which was incorporated into the chromatographic column. The two peaks with $30 \mathrm{kDa}$ proteins were analyzed using $12 \%$ SDS-PAGE, the fractions of which were collected and diluted to a volume of $\sim 10 \mathrm{ml}$ and stored at $4^{\circ} \mathrm{C}$ until further use. The protein concentrations were determined using the method previously described by Lowry (19) and the $\mathrm{N}$-terminal amino acid sequences were determined using the Edman degradation method (20).

Cytotoxicity assay. An MTT assay was used to determine the effects of $\alpha$-MMC and MAP30 on cell viability and proliferation in vitro. A549 and HepG-2 cells were cultured in DMEM supplemented with $10 \%$ fetal bovine serum and maintained in an incubator at $37^{\circ} \mathrm{C}$ with $5 \% \mathrm{CO}_{2}$. Cells were trypsinized, diluted to $2 \times 10^{4} / \mathrm{ml}$ and then seeded into a $96-w e l l$ plate $\left(100 \mu \mathrm{l}\right.$ per well). Following incubation at $37^{\circ} \mathrm{C}$ for $12 \mathrm{~h}$, cells were exposed to various concentrations of $\alpha-\mathrm{MMC}$ and MAP30 $(0.5,1,2,4$ and $8 \mu \mathrm{M})$ for $24,48,72$ and $96 \mathrm{~h}$; controls were administered equivalent amounts of phosphate-buffered saline (PBS). MTT was then added to each well and the plates were incubated at $37^{\circ} \mathrm{C}$ for $4 \mathrm{~h}$. The medium was removed and $100 \mu \mathrm{l}$ dimethylsulfoxide was added to each well; optical density (OD) of the solutions was then measured at $490 \mathrm{~nm}$ (21). The percentage of inhibition was calculated using the following formula:

$$
\text { Growth Inhibition }=\frac{(\text { OD 490 control }- \text { OD } 490 \text { sample })}{\text { OD490control }} \times 100
$$

Cell cycle arrest analysis. A549 cells $\left(2 \times 10^{5}\right.$ per well) were seeded into a six-well plate and incubated at $37^{\circ} \mathrm{C}$ for $12 \mathrm{~h}$. Cells were then treated with $4 \mu \mathrm{M} \alpha$-MMC and MAP30. Following incubation for $48 \mathrm{~h}$, the cells (both viable and nonviable) were collected, washed twice with cold PBS and then fixed in $70 \%$ ethanol at $-20^{\circ} \mathrm{C}$ overnight. Harvested cells were then washed twice with cold PBS and resuspended in $500 \mu \mathrm{l}$ PBS containing $50 \mu \mathrm{g}$ RNaseA and $10 \mu \mathrm{g}$ propidium iodide, followed by incubation at $37^{\circ} \mathrm{C}$ for $30 \mathrm{~min}$ (22). Cell cycle analysis was performed using flow cytometery.

DNA fragmentation analysis. A549 cells were cultured to $\sim 70 \%$ confluence and treated with $\alpha-\mathrm{MMC}$ and MAP30 at concentrations of 1 and $4 \mu \mathrm{M}$ for $48 \mathrm{~h}$. Cisplatin was used as positive control at a concentration of $1 \mu \mathrm{M}$ under identical conditions. Viable and nonviable cells were collected and washed twice with cold PBS, then resuspended in $0.5 \mathrm{ml}$ DNA extraction buffer (100 mM Tris, $100 \mathrm{mM}$ EDTA, $200 \mathrm{mM}$ $\mathrm{NaCl}$ and $2 \%$ SDS) containing $100 \mathrm{mg} / \mathrm{ml}$ proteinase $\mathrm{K}$ and incubated at $55^{\circ} \mathrm{C}$ for $3 \mathrm{~h}$. DNA was extracted using phenol and precipitated with $95 \%$ ethanol for $2 \mathrm{~h}$ at $-20^{\circ} \mathrm{C}$. The solution was centrifuged at $10,000 \mathrm{x}$ g at $4^{\circ} \mathrm{C}$ for $15 \mathrm{~min}$ and the pellet was then air-dried and dissolved in $20 \mu 1$ Tris/EDTA containing $20 \mu \mathrm{g} / \mathrm{ml}$ RNase; DNA was then electrophoresed over 2\% agarose gel in Tris-acetate-EDTA buffer. The bands were visualized and images were captured using an ultraviolet (UV) transilluminator (23).

Determination of SOD activity. All experiments were performed at $25^{\circ} \mathrm{C}$. The initial solution consisted of $10 \mu 1180 \mathrm{mM}$ fresh pyrogallol solution in $3 \mathrm{ml} 0.1 \mathrm{M}$ Tris- $\mathrm{HCl}(\mathrm{pH} 8.2)$ and the increase in the OD of the mixture was recorded over $3 \mathrm{~min}$ at $420 \mathrm{~nm}$ in 


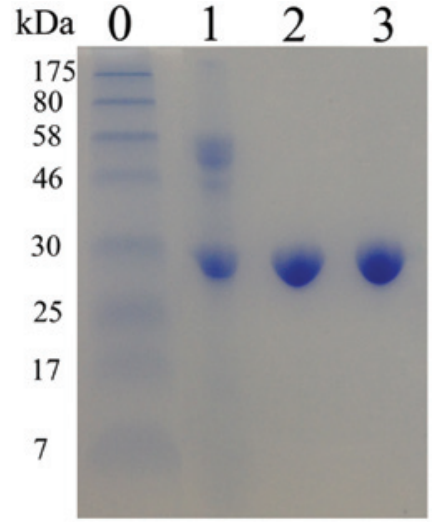

Figure 1. SDS-PAGE of crude extracts, $\alpha$-MMC and MAP30. Lanes are as follows: 0, protein marker; 1, crude extract; 2, $15 \mu \mathrm{g} \alpha$-MMC; and 3, $15 \mu$ g MAP30. $\alpha$-MMC, $\alpha$-momorcharin; MAP30, momordica anti-human immunodeficiency virus protein.

a UV spectrophotometer. In a separate solution, $10 \mu 1180 \mathrm{mM}$ pyrogallol solution was added to $3 \mathrm{ml} 0.1 \mathrm{M}$ Tris- $\mathrm{HCl}$ (pH 8.2) containing $\alpha$-MMC, MAP30 or crude extract solution at the final concentration of $10 \mu \mathrm{M}$. The rates of pyrogallol autoxidation in each solution were then measured. SOD activity was defined as the amount of enzyme that inhibited the pyrogallol autoxidation by $50 \%$ (24).

Determination of SOD activity using PAGE-NBT staining. The samples of $\alpha$-MMC, MAP30 and crude extract were loaded onto $4-12 \%$ (w/v) gradient polyacylamide gels. Following electrophoresis, half of the gels were stained using $375 \mu \mathrm{M}$ NBT solution. Following $45 \mathrm{~min}$ of incubation in the dark, the gel was then exposed to light in $50 \mathrm{mM} \mathrm{PB}$ (pH 7.8) containing $28 \mu \mathrm{M}$ riboflavin, $28 \mathrm{mM}$ tetramethylethylenediamine and $10 \mathrm{mM}$ EDTA-Na for $30 \mathrm{~min}(25)$. Simultaneously, the remaining half of the gels were stained with Coomassie brilliant blue R-250.

Statistical analysis. SPSS version 15.0 statistical software and Studen't t-test were used for analysis. Values are presented as the mean \pm standard error of the mean or mean value \pm standard deviation. $\mathrm{P}<0.05$ was considered to indicate a statistically significant difference between values.

\section{Results}

Purification of $\alpha-M M C$ and MAP30. Purification of $\alpha-M M C$ and MAP30 was performed using ammonium sulfate precipitation and acidification as well as SP-sepharose FF, Sephacryl S-100 and Macro-Cap-SP chromatography. A total of $210 \mathrm{mg} \alpha$-MMC and $100 \mathrm{mg}$ MAP30 were obtained from $200 \mathrm{~g}$ starting material seeds. SDS-PAGE was then used to assess the protein fractions of $\alpha-M M C$ and MAP30 (Fig. 1). In addition, Edman degradation analysis revealed that the $\mathrm{N}$-terminal sequences of the purified proteins, $N$-Asp-Val-Ser-Phe-Arg and $N$-Asp-Val-Asn-Phe-Asp, were consistent with the theoretical sequences of $\alpha-\mathrm{MMC}$ and MAP30.

Inhibitory effects of $\alpha-M M C$ and MAP30 on the proliferation of A549 and HepG-2 cells. As shown in Fig. 2, following
A

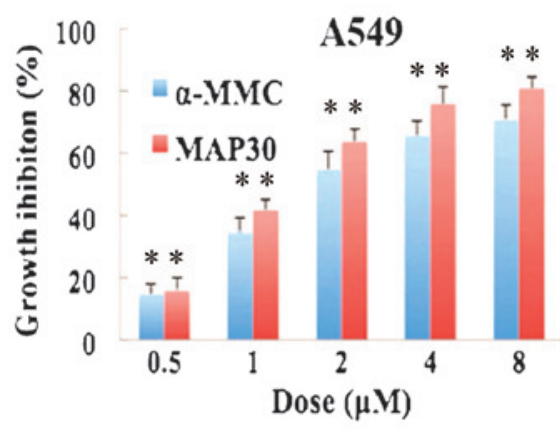

B

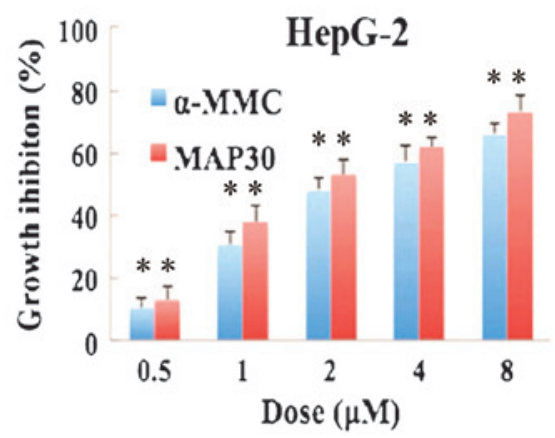

C

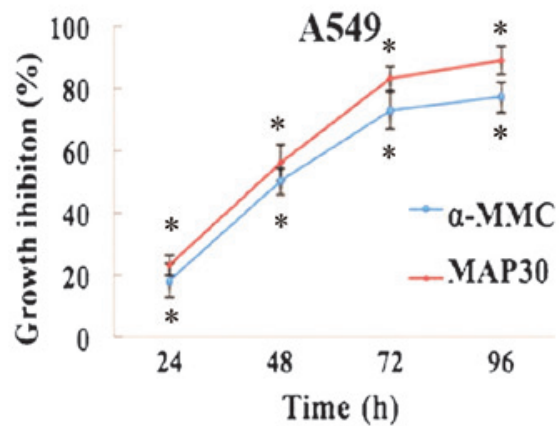

D

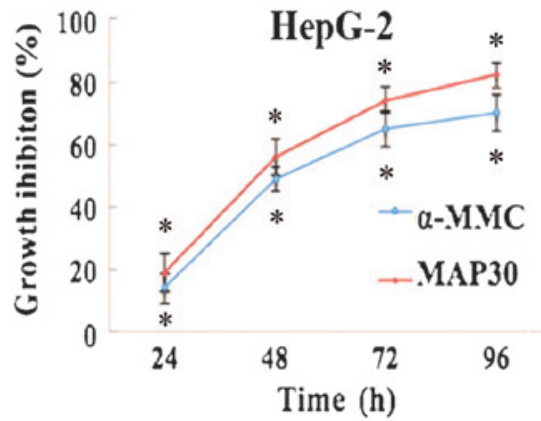

Figure 2. Inhibitory effects of $\alpha$-MMC and MAP30 on the proliferation of A549 and HepG-2 cells relative to the growth of the control. An MTT assay was used to determine the growth inhibition rates of cells treated with $\alpha-\mathrm{MMC}$ and MAP30. (A) A549 and (B) HepG-2 cells were treated with various concentrations of $\alpha$-MMC or MAP30 $(0.5,1,2,4$ and $8 \mu \mathrm{M})$ for 72 h. (C) A549 and (D) HepG-2 cells were treated with $8 \mu \mathrm{M} \alpha$-MMC or MAP30 for $24,48,72$ and $96 \mathrm{~h}$. Values are presented as the mean \pm standard deviation $(\mathrm{n}=4) .{ }^{*} \mathrm{P}<0.05$ vs. control (0). $\alpha$-MMC, $\alpha$-momorcharin; MAP30, momordica anti-human immunodeficiency virus protein.

treatment with $\alpha$-MMC or MAP30, the viability of A549 and HepG-2 cells was decreased in a time- and dose-dependent manner, with significant cell growth inhibition at 72 and $96 \mathrm{~h}$ post-treatment as well as all concentrations $\geq 2 \mu \mathrm{M} \alpha$-MMC or MAP30. In addition, the results indicated that MAP30 exhibited more potent anti-tumor effects compared to those 
Table I. Comparison of the SOD activity of the crude extract of bitter melon seeds, MAP30 and $\alpha$-MMC.

\begin{tabular}{lccc}
\hline Sample & Concentration $(\mu \mathrm{g} / \mathrm{ml})$ & Autoxidation rate $(\Delta \mathrm{OD} / \mathrm{min})$ & SOD activity $(\mathrm{U} / \mathrm{ml})$ \\
\hline Crude extract & 330 & $0.028 \pm 0.0006^{\mathrm{a}}$ & $75 \pm 2.3$ \\
MAP30 & 330 & $0.056 \pm 0.0003$ & 0 \\
$\alpha-$ MMC & 330 & $0.056 \pm 0.0002$ & 0 \\
Control & - & $0.056 \pm 0.0002$ & 0 \\
\hline
\end{tabular}

SOD activity of $\alpha$-MMC and MAP30 was not detected at concentrations of $330 \mu \mathrm{g} / \mathrm{ml}$, while the SOD activity of crude extract was measured to be $\sim 75 \mathrm{U} / \mathrm{ml}$ under identical conditions. ${ }^{a} \mathrm{P}<0.05$ vs. control. SOD, superoxide dismutase; $\alpha$-MMC, $\alpha$-momorcharin; MAP30, momordica anti-human immunodeficiency virus protein.
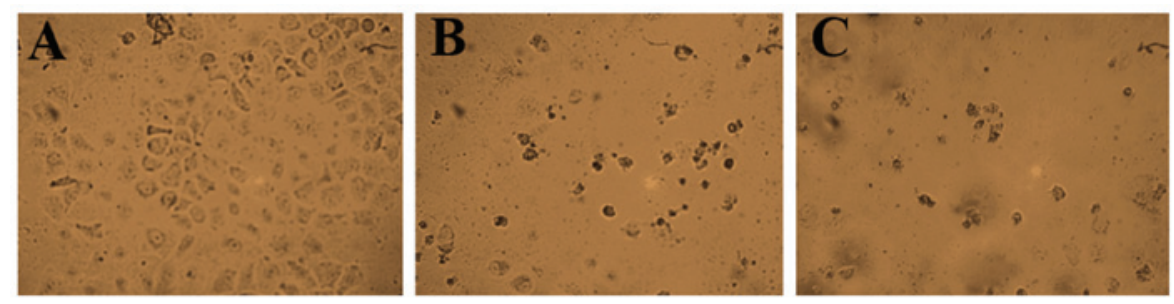

Figure 3. Effects of $\alpha$-MMC and MAP30 on the micro-morphology of A549 cells (magnification, $\mathrm{x} 200$ ). (A) Untreated cells, (B) cells treated with $8 \mu \mathrm{M} \alpha-\mathrm{MMC}$ and (C) cells treated with $8 \mu \mathrm{M}$ MAP30 for $72 \mathrm{~h}$. $\alpha$-MMC, $\alpha$-momorcharin; MAP30, momordica anti-human immunodeficiency virus protein.
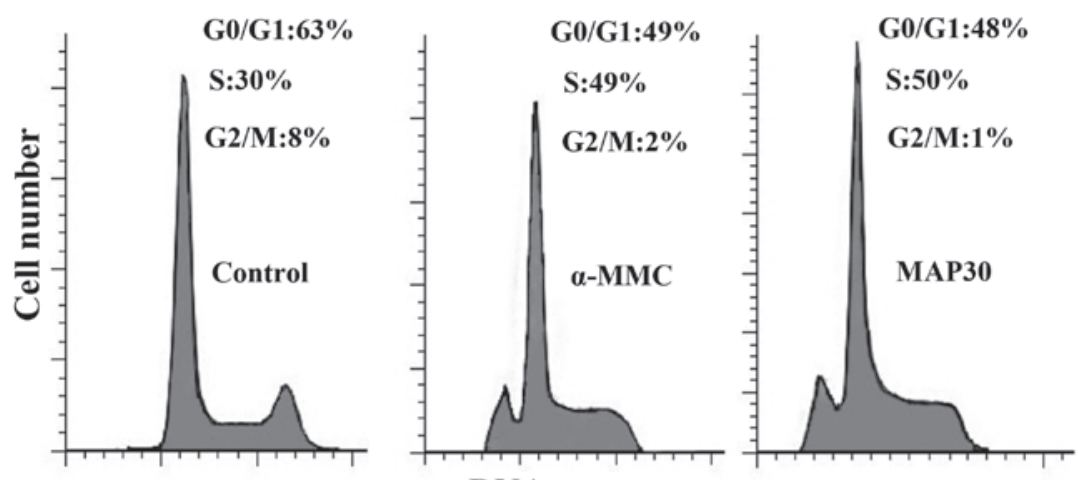

DNA content

Figure 4. DNA flow cytometric analysis. A549 cells were treated with $4 \mu \mathrm{M} \alpha$-MMC or MAP30 for $48 \mathrm{~h}$ and analyzed by flow cytometry. Percentages of cells in $\mathrm{G}_{0} / \mathrm{G}_{1}, \mathrm{~S}$ and $\mathrm{G}_{2} / \mathrm{M}$ phase were calculated and are represented within the histograms. $\alpha-\mathrm{MMC}$, $\alpha$-momorcharin; MAP30, momordica anti-human immunodeficiency virus protein.

of $\alpha$-MMC. As shown in Fig. 3, phase contrast microscopy revealed that untreated cells grew well and displayed extended and flat cell shape, whereas cells treated with $\alpha$-MMC or MAP30 for $72 \mathrm{~h}$ demonstrated typical apoptotic morphological changes, including shrinkage, blebbing and loss of membrane asymmetry.

$\alpha-M M C$ and MAP30 treatment significantly increase cell cycle arrest. Flow cytometric analysis demonstrated a significantly increased rate of cell cycle arrest of A549 cells in $\mathrm{S}$ phase following treatment with $4 \mu \mathrm{M} \alpha$-MMC or MAP30 for $48 \mathrm{~h}$ (Fig. 4). In addition, the results showed that treated cells had a decreased proportion of cells in $\mathrm{G}_{0} / \mathrm{G}_{1}$ phase and $\mathrm{G}_{2} / \mathrm{M}$ phase; furthermore, the appearance of hypodiploid peaks in the treated groups indicated a large number of apoptotic cells (Fig. 4B and C).
DNA fragmentation analysis. As shown in Fig. 5, following exposure of A549 cells to $\alpha$-MMC or MAP30 at concentrations of 1 and $4 \mu \mathrm{M}$ for $48 \mathrm{~h}$, gel electrophoresis did not reveal any typical apoptotic DNA fragmentation pattern in A549 cells. Instead, DNA was shown to be degraded into small fragments, which increased in a dose-dependent manner. However, following treatment of A549 cells with cisplatin, a typical apoptotic pattern was observed.

Analysis of SOD activity by pyrogallol autoxidation and NBT-PAGE. The rate of pyrogallol autoxidation was $0.056 \mathrm{~min}^{-1}$ in the reaction system without RIPs and $0.028 \mathrm{~min}^{-1}$ in the same reaction system containing $330 \mu \mathrm{g} / \mathrm{ml}$ total protein of crude extract, which indicated that the SOD activity of crude extract was $\leq 75 \mathrm{U} / \mathrm{ml}$. However, when the concentrations of $\alpha$-MMC or MAP30 were the same as that of crude extract in 


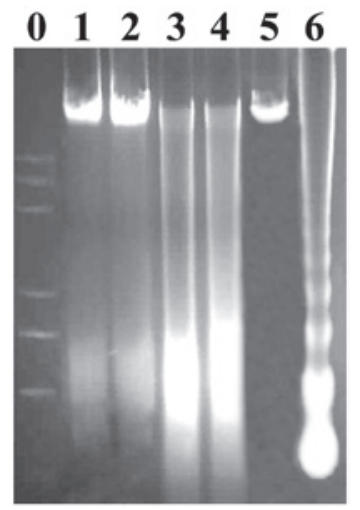

Figure 5. $\alpha$-MMC- and MAP30-induced dose-dependent DNA fragmentation A549 cells were treated with various concentrations of $\alpha$-MMC and MAP30 for $72 \mathrm{~h}$, then analyzed by $2 \%$ agarose gel electrophoresis. Lanes: 0 , molecular weight marker; 1, $1 \mu \mathrm{M} \alpha$-MMC; 2, $1 \mu \mathrm{M}$ MAP30; 3, $4 \mu \mathrm{M} \alpha$-MMC; 4, $4 \mu \mathrm{M}$ MAP30; 5, control; and 6, $1 \mu \mathrm{g} / \mathrm{ml}$ cisplatin. $\alpha$-MMC, $\alpha$-momorcharin; MAP30, momordica anti-human immunodeficiency virus protein.

the reaction system, the rate of pyrogallol autoxidation was $0.056 \mathrm{~min}^{-1}$, indicating that $\alpha-\mathrm{MMC}$ and MAP30 did not have SOD activity (Table I).

As shown in Fig. 6, following staining with NBT, the lane of the crude extract from Momordica charantia revealed an SOD activity band; however, a SOD activity band was not observed in the sites corresponding to $\alpha$-MMC and MAP30.

\section{Discussion}

At present, numerous types of chemotherapeutic agents are used in cancer therapy, which kill cells through mechanisms other than apoptosis. This may not always be a preferable way of cancer management, as it may result in adverse effects. However, certain RIPs have been reported to exhibit minimal or no adverse effects on normal cells as they recognize membrane features which are unique or dominant in tumor cells (26); for example, MAP30 was reported to be non-toxic to human spermatozoa at the doses at which it inhibited human immunodeficiency virus-1 and the herpes simplex virus (27). This therefore indicated that $\alpha$-MMC and MAP30 may serve as novel agents for the prophylaxis and treatment of cancer. The present study investigated the anti-tumorigenic mechanisms of $\alpha$-MMC and MAP30 extracted from Momordica charantia seeds, as well as determined whether they exhibited SOD activity. The results of the present study showed that MAP30 and $\alpha$-MMC induced cell cycle arrest and subsequent apoptotic death in A549 cells in a dose- and time-dependent manner. In addition, the results demonstrated that SOD activity was not observed in solutions containing $\alpha$-MMC and MAP30, whereas SOD activity was observed in the reaction systems containing crude extract from Momordica charantia.

In the present study, following treatment with $\alpha-\mathrm{MMC}$ and MAP30, significant cytotoxic effects were observed in A549 and HepG-2 cells, including significant growth inhibition and increased apoptosis, which were most significant in the $8 \mu \mathrm{M}$ treatment groups. In addition, phase contrast microscopy revealed that terminal stage apoptotic cells and necrotic cells were dominant following treatment with $\alpha$-MMC and MAP30 for $72 \mathrm{~h}$. Furthermore, the results indicated that MAP30 had a

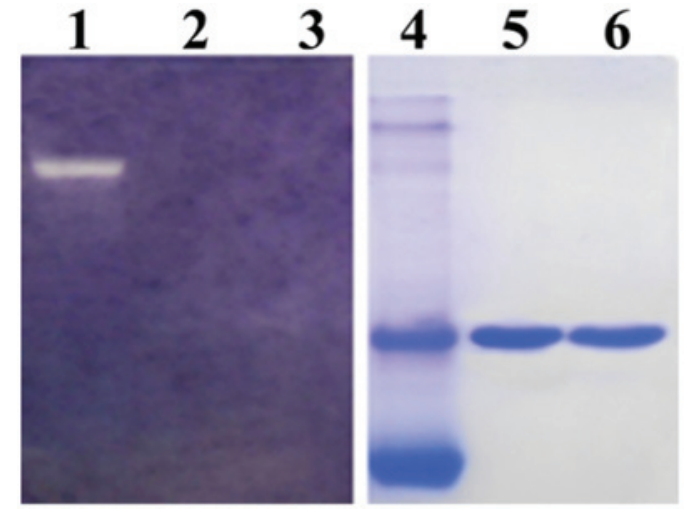

Figure 6. Superoxide dismutase activity of crude extract, MAP30 and $\alpha$-MMC from bitter melon seeds. Lanes 1-3 were stained with nitrotetrazolium blue chloride and lanes 4-6 were stained with Coomassie brilliant blue R-250. Lanes: 1 and 4, $50 \mu \mathrm{g}$ crude extract of bitter melon seeds; 2 and 5 , $20 \mu \mathrm{g} \alpha$-MMC; 3 and 6, $20 \mu \mathrm{g}$ MAP30. $\alpha$-MMC, $\alpha$-momorcharin; MAP30, momordica anti-human immunodeficiency virus protein.

more potent anti-tumor effect compared with that of $\alpha$-MMC, whose proportion in Momordica charantia seeds was twice of that of MAP30.

Apoptosis is an essential regulatory mechanism in the behavior of mammalian cells in numerous situations (28). The apoptotic program is characterized by particular morphological features, which differ from those of necrotic cell death (29-32). In the present study, following treatment of A549 cells with $\alpha$-MMC and MAP30, numerous typical features of the apoptotic pathway were observed, including cell shrinkage, alteration of internal membrane of the mitochondria and the formation of apoptotic bodies. However, a classical DNA fragmentation pattern was not observed using agarose gel electrophoresis following treatment with $\alpha$-MMC or MAP30. One explanation for this may be that RIPs, including $\alpha$-MMC and MAP30, may recognize DNA as well as RNA as substrates for hydrolysis (33).

In the present study, an accumulation of cells in $\mathrm{S}$ phase and a decline in the $\mathrm{G}_{0} / \mathrm{G}_{1}$ and $\mathrm{G}_{2} / \mathrm{M}$ phase populations was observed following treatment with $\alpha-\mathrm{MMC}$ and MAP30. This may be due to rRNA damage induced by the two RIPs. Cells with damaged ribosomes are unable to transition from $\mathrm{S}$ phase into $G_{2} / M$ phase, which in turn affects DNA synthesis. The effects of $\alpha$-MMC and MAP30 on S phase cell cycle arrest in A549 cells indicated their potential use as novel therapeutic agents for the control of cancer growth, as the majority of cancer types have been reported to have defects in one or more cell cycle checkpoints $(34,35)$. In addition, in the present study, the presence of a subG $\mathrm{G}_{0} / \mathrm{G}_{1}$ population amongst cells treated with $\alpha$-MMC and MAP30 demonstrated that these RIPs may induce apoptosis as a result of intracellular DNA leaking.

Molecular damage due to reactive oxygen species (ROS), in particular $\mathrm{O}_{2}^{-}$and its derivatives, is a primary cause of aging (36). The enzyme SOD converts $\mathrm{O}_{2}{ }^{-}$into $\mathrm{H}_{2} \mathrm{O}_{2}$, which in turn is converted into $\mathrm{H}_{2} \mathrm{O}$ and $\mathrm{O}_{2}$. Therefore, SOD is important for health maintenance and the prevention of chronic diseases (37). In addition, the SOD activity of RIPs may enhance the potential of their future applications. In the present study, the SOD activity of $\alpha$-MMC and MAP30 was analyzed using pyrogallol autoxidation and NBT-negative 
activity staining, the results of which revealed that, contrary to previous studies on other RIPs (17), $\alpha$-MMC and MAP30 did not induce any SOD activity.

In conclusion, the results of the present study demonstrated that the mechanisms underlying the cytotoxic effects of $\alpha$-MMC and MAP30 were independent of SOD activity; however, the two RIPs were able to suppress the proliferation of tumor cells in vitro as well as induce apoptosis and cell cycle arrest in A549 cells. This therefore indicated that $\alpha$-MMC and MAP30 may be promising novel therapeutic agents for the prophylaxis and treatment of cancer. Future studies are required in order to determine the most suitable method of $\alpha$-MMC and MAP30 administration, possibilities of which include intraperitoneal injection and intratumoral treatment.

\section{Acknowledgements}

The present study was supported by the National Science Foundation of China (grant nos. 30770232 and J1103518).

\section{References}

1. Mentreddy SR: Review-medicinal plant species with potential antidiabetic properties. Sci Food Agric 87: 743-750, 2007.

2. Pieroni A, Houlihan L, Ansari N, Hussain B and Aslam S: Medicinal perceptions of vegetables traditionally consumed by South-Asian migrants living in Bradford, Northern England. J Ethnopharmacol 113: 100-110, 2007.

3. Fang EF and Ng TB: Bitter gourd (Momordica charantia) is a cornucopia of health: a review of its credited antidiabetic, anti-HIV and antitumor properties. Curr Mol Med 11: 417-436, 2011.

4. Schaefer H and Renner SS: A three-genome phylogeny of Momordica (Cucurbitaceae) suggests seven returns from dioecy to monoecy and recent long-distance dispersal to asia. Mol Phylogenet Evol 54: 553-560, 2010.

5. Fang EF, Ng TB, Shaw PC and Wong RN: Recent progress in medicinal investigations on trichosanthin and other ribosome inactivating proteins from the plant genus trichosanthes. Curr Med Chem 18: 4410-4417, 2011.

6. Hartley MR, Chaddock JA and Bonness MS: The structure and function of ribosome-inactivating proteins. Trends Plant Sci 1: p252, 1996.

7. Mock JW, Ng TB, Wong RN, et al: Demonstration of ribonuclease activity in the plant ribosome-inactivating proteins alpha- and beta-momorcharins. Life Sci 59: 1853-1859, 1996.

8. Fang EF, Zhang CZ, Fong WP and Ng TB: RNase MC2: a new Momordica Charantia ribonuclease that induces apoptosis in breast cancer cells associated with activation of MAPKS and induction of caspase pathways. Apoptosis 17: 377-387, 2011.

9. Wang YX, Jacob J, Wingfield PT, Palmer I, Stahl SJ, Kaufman JD, Huang PL, Huang SL, Torchia DA, et al: Anti-HIV and anti-tumor protein MAP30, a $30 \mathrm{kDa}$ single-strand type-I Rip, shares similar secondary structure and $\beta$-sheet topology with the A chain of ricin, A type-II Rip. Protein Sci 9:138-144, 2008.

10. Lee-Huang S, Huang PL, Nara PL, et al: MAP 30: a new inhibitor of HIV-1 infection and replication. FEBS Lett 272: 12-18, 1990.

11. Lee-Huang S, Huang PL, Bourinbaiar AS, et al: Inhibition of the integrase of human immunodeficiency virus (HIV) Type 1 by anti-HIV plant proteins MAP30 and GAP31. Proc Natl Acad Sci USA 92: 8818-8822, 1995.

12. Xiong SD, Yu K, Liu XH, Yin LH, Kirschenbaum A, Yao S, Narla G, et al: Ribosome-inactivating proteins isolated from dietary bitter melon induce apoptosis and inhibit histone deacetylase-1 selectively in premalignant and malignant prostate cancer cells. Int J Cancer 125: 774-782, 2009.

13. Yao X,Li J, Deng N, Wang S, Meng Y and Shen F: Immunoaffinity purification of $\alpha$-momorcharin from bitter melon seeds (momordica charantia). J Sep Sci 34: 3092-3098, 2011.
14. Bian X, Shen F, Chen Y, Wang B, Deng M and Meng Y: PEGylation of alpha-momorcharin: synthesisand characterization of novel anti-tumor conjugates with therapeutic potential. Biotechnol Lett 32: 883-890, 2010.

15. Li XD, Chen WF, Liu WY and Wang GH: Large-scale preparation of two new ribosome inactivating proteins-cinnamomin and camphorin from the seeds of cinnamomum camphora. Protein Expr Purif 10: 27-31, 1997.

16. Sharma N, Park SW, Vepachedu R, et al: Isolation and characterization of an RIP (ribosome-inactivating protein)-like protein from tobacco with dual enzymatic activity. Plant Physiol 134: 171-181, 2004.

17. Fu MH and Tian J: Isolation, purification and anti-oxidation of ribosome-inactivated proteins from seeds of Momordica charantia L. Zhongguo Sheng Hua Yao Wu Za Zhi 3: 134-136, 2002 (In Chinese).

18. Meng Y, Liu B, Lei N, Zheng J, He Q, Li D, Zhao X and Shen F: Alpha-momorcharin possessing high immunogenicity, immunotoxicity and hepatotoxicity in SD rats. J Ethnopharmacol 139: 590-598, 2012.

19. Fryer HJ, Davis GE, Manthorpe M and Varon S: Lowry protein assay using an automatic microtiter plate spectrophotometer. Anal Biochem 153: 262-266, 1986.

20. Niall HD: Automated Edman degradation: the protein sequenator. Meth Enzymol 27: 942-1010, 1973.

21. Sargent JM and Taylor CG: Appraisal of the MTT assay as a rapid test of chemosensitivity in acute myeloid leukaemia. Br J Cancer 60: 206-210, 1989.

22. Shiffn SJ, Koutsos MI, Qiao L and Rigas B: Nonsteroidal antiinflammatory drugs inhibit the proliferation of colon adenocarcinoma cells: effects on cell cycle and apoptosis. Exp Cell Res 222: 179-188, 1996.

23. Lu J, Kaeck M, Jiang C, Wilson AC and Thompson HJ: Selenite induction of DNA strand breaks and apoptosis in mouse leukemic L1210 cells. Biochem Pharmacol 47: 1531-1535, 1994.

24. Roig R, Cascon E, Arola L, Blade C and Salvado MJ: Moderate red wine consumption protects the rat against oxidation in vivo. Life Sci 64: 1517-1524, 1999.

25. Beauchamp C and Fridovich I: Superoxide dismutase: improved assays and an assay applicable to acrylamide gels. Anal Biochem 44: 276-287, 1971.

26. Ling J and Liu WY: Cytotoxicity of two new ribosome-inactivating proteins, cinnamomin and camphorin, to carcinoma cells. Cell Biochem Funct 14: 157-161, 1996.

27. Schreiber CA, Wan L, Sun Y, Lu L, Krey LC and Lee-Huang S: The antiviral agents, MAP30 and GAP31, are not toxic to human spermatozoa and may be useful in preventing the sexual transmission of human immunodeficiency virus type 1 . Fertil Steril 72: 686-690, 1999.

28. Kerr JFR, Wyllie AH and Currie AR: Apoptosis: a basic biological phenomenon with wide-ranging implications in tissue kinetics. Br J Cancer 26: 239-257, 1972.

29. Thompson CB: Apoptosis in the pathogenesis and treatment of disease. Science 267: 1456-1462, 1995.

30. Trump BF, Berezesky IK, Chang SH and Phelps PC: The pathways of cell death: oncosis, apoptosis and necrosis. Toxicol Pathol 25: 82-88, 1997.

31. Goldsworthy TL, Conolly RB and Fransson Steen R: Apoptosis and cancer risk assessment. Mutat Res 365: 71-90, 1996.

32. Stuart MC, Damoiseaux JG, Frederik PM, Arends JW and Reuteulingsperger CPM: Surface exposure of phosphatidylserine during apoptosis of rat thymocytes precedes nuclear changes. Eur J Cell Biol 76: 77-83, 1998.

33. Lee-Huang S, Kung HF, Huang PL, et al: Human immunodeficiency virus type 1 (HIV-1) inhibition, DNA-binding, RNA- binding and ribosome inactivation activities in the N-terminal segments of the plant anti-Hiv protein GAP31. Proc Natl Acad Sci USA 91: 12208-12212, 1995.

34. Hartwell LH and Kastan MB: Cell cycle control and cancer. Science 266: 1821-1828, 1994.

35. Dulic V, Kaufmann WK, Wilson SJ, Tlsty TD, Lee SE, Harper JW, et al: P53-dependent inhibition of cyclin-dependent kinase activities in human fibroblasts during radiation-induced G1 arrest. Cell 76: 1013-1023, 1994.

36. Beckman KB and Ames BN: The free radical theory of aging matures. Physiol Rev 78: 547-581, 1998.

37. Sardesai VM: Role of antioxidants in health maintenance. Nutr Clin Pract 10: 19-25, 1995. 